\title{
Analysis on Conversational Implicature in Downton Abbey Season One from the Perspective of the Cooperative Principle
}

张莉 李敏杰*

Article History

Received: 20.08 .2020

Accepted: 06.09.2020

Published: 30.09 .2020

Journal homepage:

https://www.easpublisher.com/easjhcs

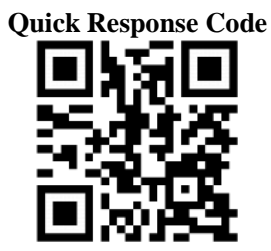

Abstract: Grice, a famous American linguist, put forward the Cooperative Principle for the first time. He stressed that in daily communication, in order to make a smooth conversation, both sides have to abide by a certain principle without being noticed, that is the Cooperative Principle. The core of the cooperative principle is its four maxims: quantity, quality, relation and manner maxim. However, Grice found that people, in reality, is almost impossible to obey the cooperative principle all the time, and they often said something irrelevant to current topics to convey their true meaning, which is defined as the Conversational Implicature by Grice. This paper, taking the dialogues of the characters in Downton Abbey as the script and the cooperative principle as the theoretical framework, illustrates in detail the conversational implicature created by violating the cooperative principle in the dialogue among the characters in the play.

Keywords: Cooperative Principle; Conversational Implicature; Downton Abbey.

Copyright (C) 2020 The Author(s): This is an open-access article distributed under the terms of the Creative Commons Attribution 4.0 International License (CC BY-NC 4.0) which permits unrestricted use, distribution, and reproduction in any medium for non-commercial use provided the original author and source are credited.

\section{INTRODUCTION}

This paper mainly analyzes the conversational implicature of some classic dialogues in Downton Abbey Season One from the perspective of cooperative principle. Cooperative principle was first presented by Grice (1967) in one of his lectures "Logic and conversation". He explained the definition of the cooperative principle and its four maxims: quantity, quality, relation and manner maxim. Grice stressed that people should obey cooperative principle in real conversation, however, in most cases, it is obviously impossible for people to achieve it, and they always violated these four maxims. That is to say, what speakers' real intention will not be reflected in what speaker said on the surface. Therefore, this paper mainly takes the characters' dialogues from Downton Abbey as real examples to illustrate the implicature. This paper is going to explore why people fail to strictly obey the maxims of the cooperative principle by analyzing the implied meaning of dialogues in Downton Abbey Season One.

\section{Theoretical Basis}

\section{Four Maxims of Cooperative Principle}

According to Grice, there are four maxims included in Cooperative Principle as following: quantity, quality, relation, and manner. These conversational maxims, to some extent, guarantee speakers and hearers who strictly obey these maxims to have a smooth and successful conversation. However, these maxims are not invariable but flexible. People sometimes may violate these maxims deliberately for reasons of humor, manner, avoiding embarrassment, etc. That is the reason why conversational implicature occurs.

\section{Quantity Maxim}

According to Grice, the maxim of quantity includes two aspects, they are:

(1). Make your contribution as informative as is required for the current purpose of the exchange.

(2). Do not make your contribution more informative than is required.

(Grice, 1975: 46)

Actually, Grice stressed that both speaker and hearer should give enough information to each other in an attitude of cooperation, avoiding information deficiency and redundant content in the real conversation.

There is an example to illustrate it: Example 1:

A: Do you know where my bag is?

B: Yes, in my room. 
In example 1, B directly gives the information to A, no less and no more. Thus, A do not bother to infer from B' utterance, and we can see the quantity maxim is obeyed. However, in real conversation, the conversation is not so simple and the conversation maxims are always violated.

\section{Example 2:}

A: Do you know where my bag is?

B: Yes. (Then B did not say more...)

In example 2, B actually knows where A's bag is. Although B gives A a positive answer, B does not offer enough information that $A$ required. The implied meaning of $\mathrm{B}$ perhaps is that $\mathrm{B}$ wants to play a joke with $\mathrm{A}$ or $\mathrm{B}$ does not want to tell A for some reasons. Therefore, B violates the maxim of quantity for offering less information that A really required.

\section{Quality Maxim}

On the one hand, the maxim of quality stresses that the speakers are required to provide true information for hearers. On the other hand, in order to guarantee to an effective conversation, speaker should not provide information without relevant evidence. According to Grice, the quality maxim includes two aspects:

(1). Do not say what you believe to be false.

(2). Do not say that for which you lack adequate evidence.

(Grice, 1975: 46)

\section{The following is an example to illustrate the quality maxim:}

Example 3:

A: Where is the Municipal People's Hospital?

B: Eh...I don't know.

In example 3, if B does not tell a lie, B obeys the maxim of quality because he really has no idea about the location of the Municipal people's hospital. On the contrary, if B actually knows the location of the Municipal People's Hospital but B does not want to tell A for some reasons. So B hesitates for a moment with answer "Eh", then tells A a lie in an uncooperative attitude. B's answer apparently violates the maxim of quality.

\section{Relation Maxim}

According to Grice, the maxim of relation refers to that the information provided by speaker should be relevant to the conversation at hand so that they can achieve a successful and coherent communication. Sperber and Wilson (1986) thought: “ relevance is the process of inferring relevant information from any given utterance". However, people always say something that has little to do with the present topics in order to create a pleasant atmosphere or avoid someone losing face in our daily life. We can say they violate the relation maxim.

\section{Example 4:}

A: Have you finished your homework?

B: Emm...I went on a picnic yesterday with my parents and we had a goog time.

In this example, $\mathrm{A}$ asks $\mathrm{B}$ about the homework, but B changes another topic telling A that he went on a picnic yesterday. B apparently violates the maxim of relation, because B's utterance is not related with A's question. It is no doubt that B's answer may convey some other implied implicature. We can infer from B's utterance that B does not finish homework yet or $\mathrm{B}$ does not want to pay attention to A, because B hates $\mathrm{A}$. Therefore, in order to avoid embarrassment or take a polite attitude, B says something irrelevant to A.

\section{Manner Maxim}

The maxim of manner refers to that people should convey their meaning clearly, orderly and concisely during a conversation. This maxim includes four aspects:

(1). Avoid obscurity of expression.

(2). Avoid ambiguity.

(3). Be brief.

(4). Be orderly.

(Grice, 1975: 46)

However, there are still a large number of people violating the manner maxim for different purposes, so hearers have to infer the real intention from speakers' obscure utterance.

\section{Example 5:}

A: I want to buy a gift for my daughter.

B: Okay, but I do not recommend C-A-N-D-Y.

In this dialogue, B's answer may confuse A: "Why don't B say "candy" directly but indirectly spells out the word "C-A-N-D-Y"? There is no doubt that A's daughter is also here, and B does not want her to hear what they are talking about because the candy is harmful to little kids' teeth. If A's daughter hears it, she will cry. Overall, however, B violates the manner maxim.

In summary, these four maxims are the core of Cooperative Principle. In our daily life, we inevitably have to interact with others, thus it is particularly important to master some conversational maxims. We not only need to understand what the speaker literally said, but also should grasp the implied meaning behind the speaker's utterance according to a certain context.

\section{Case Analysis of Conversational Implicature in Downton Abbey \\ Conversational Implicature Created by Violating the Maxim of Quantity}

In an ideal conversation, both speaker and hearer should take a cooperative attitude to offer sufficient information as required to each other, no 
more or no less. However, the most common thing in life is that people always provide more or less information for each other to convey some implied meanings. The dialogues in Downton Abbey season one are no exception.

\section{Less Information}

In reality, we can say the speaker violated the maxim of quantity if the speaker offered less information than is required to the hearer. However, it can be affirmed that speaker must want to convey some implied meaning to hearer, while the speaker cannot express it directly in order to take care of hearer's emotions. The hearer needs to guess the meaning that speaker really want to tell. The following lines were taken form British series Downton Abbey.

\section{Example 1:}

Mr.Carson: Oh, I do take it personally, Mrs. Hughes. I can't stand by and watch our family threatened with the loss of all they hold.

Mrs. Hughes: They are not our family.

Mr. Carson: Well, they are all the family I've got.

(Mrs. Hughes pondered for a moment, and said shyly)

Mrs. Hughes: Do you... ever wish you'd gonna another way? ...worked in a shop or a factory?

Mr.Carson: Do you?

Mrs. Hughes: I don't know. Maybe, sometimes.

(Downton Abbey, Episode 1)

In this dialogue, Mrs. Hughes actually wanted to know whether Carson liked her, just as she liked him, so she said to Carson: "Do you... ever wish you'd gonna another way? ... worked in a shop or a factory". Her implicature was that she wanted Carson to quit his job and start a completely new life with him outside. But Carson had already regarded Downton Abbey as his own home, his own family. So he said in displeasure "Do you?" From his utterances, we can clear that he pretended that he didn't make sense of Mrs. Hughes intentions and indirectly asked her if she regretted staying here. Behind Carson's utterances, his implicature is that "I do not like you, I do not want to quit my present job and I am merely willing to stay with my family in Downton Abbey". Mr. Carson and Mrs. Hughes's dialogues obviously violate the maxim of quantity, because Carson offered little useful information to Mrs. Hughes than was required.

\section{More Information}

Opposite to offering less information, speakers also might offer more information than is required. Thus the speaker violates the maxim of quantity by saying more than required information. The exceeding information usually expresses conversational implicature. In Downton Abbey, the following is one of those cases.

\section{Example 2:}

Robert: He didn't spoil anything. He fell over.

Cora: It was so undignified. Carson hates that kind of thing.

(Downton Abbey, Episode 1)

This dialogue took place in living room where Robert and his wife Cora was talking about the Carson's fall this afternoon. Cora's maid Brien tripped up Bates on purpose while no one else noticed. All the people were shocked by Bate's embarrassment but nobody wanted to help him except Robert and Anna. After this, the hostess Cora was even more dissatisfied with Bates and then complained to her husband Robert "It was so undignified, Carson hates that kind of thing". From Cora's utterance, it can be affirmed that she felt dissatisfied with this matter, but she did not directly put her cards on the table, so she explained it on the grounds that Carson didn't like that kind of thing.

\section{Conversational Implicature Created by Violating the Maxim of Quality}

The maxim of quality refers to the authenticity and reliability of the conversation. It requires speaker not to tell a lie or offer some information without sufficient evidence. However, in daily life, people always tell a lie on purpose or provide the false information due to politeness, privacy and personal interest, which can be regarded as violation of quality maxim. In this maxim, it is very common to use figures of speech to convey the true mind, most often, Metaphor, irony and hyperbole often appear in daily conversation (Cheng Yumin, 1983).

\section{Metaphor}

Metaphor is one kind of rhetorical figures. Metaphor is an indirect expression which is used to refer to something that it does not literally denote in order to suggest a similarity. Therefore, using metaphor can be regarded as violation of quality maxim. In certain contexts, employment of metaphor can ease the tension and create a humorous and comfortable atmosphere.

\section{Example 3:}

Anna: How much did it cost?

Gwen: Every penny I'd saved, or almost.

Anna: And...is this your mystery love?

Gwen: I've been taking a correspondence course in typing and shorthand.

Anna: Are you any good?

Gwen: ...

(Downton Abbey, Episode 3)

This conversation is made by Anna and Gwen who were servants in Downton Abbey. Anna found a strange machine in Gwen's package and then asked Gwen what it is as well as how much it cost. Gwen told Anna that the machine is actually a typewriter and she 
had been taking a correspondence course in typing and shorthand. Anna was surprised and asked him for proof "And... is this your mystery love?" On the one hand, because Anna had seen Gwen receive some correspondence from outside in private before, thought that Gwen might fall in love with a right man, but now it seems not like that. The typewriter is really the Gwen's mystery lover rather than she really had a boyfriend. It is not difficult to find that Anna made use of a metaphor to express her surprise.

\section{Irony}

"The irony refers to a figure of speech that achieves emphasis by saying the opposite of what is meant, the intend meaning of the words being the opposite of their usual sense" (Feng Cuihua, 1983: 67). It means that the utterance provided by speaker might be unreality or is opposite to his implied meaning in order to be polite or keep hearer from being embarrassed. The following example illustrates how application of irony violates the quality maxim.

\section{Example 4:}

Mr. Napier: That run reminded me of a day last month, up in Cheshire, we came down the side of a hill...

Mary: Excuse me.( Then she went to Pamuk.)

Matthew: It seems we must brush up on our powers of fascination.

Mr. Napier: I was a fool to bring him her.

Matthew: Don't you like him?

Mr. Napier: Well I like him very much, but so does everyone else unfortunately.

(Downton Abbey, Episode 3)

This conversation occurs at a family party in Downton Abbey. At the party, almost all the young men including Napier felt some admiration for Mary and wanted to talk to her. Unluckily, Mary seemed to like Pamuk only, and focused all her eyes on him. Therefore, Napier said in dismay "I was a fool to bring him to her". Because it is Napier himself bringing his good friends Pamuk in front of Mary. Therefore, he made use of the expression of irony implying his mistake to express his dissatisfaction to Pamuk. Of course, from his utterance "Well I like him very much, but so does everyone else unfortunately." It is not difficult to see that he was not really dissatisfied with Pamuk, but a kind of jealousy of his charm. Napier's words "I was a fool to bring him her" actually did not describe the truth, but an irony expression implied "I shouldn't have brought Pamuk here, and it's a definitely wrong decision I've made." Therefore, Mr. Napier violated the quality maxim.

\section{Hyperbole}

Hyperbole refers to the utterance using an expression of exaggeration to stress somethings and achieve what is expected. If someone uses hyperbole, he says or writes things that may make something feel much more impressive and vivid than it really is.

\section{Example 5:}

Mary: What about Mr. Pamuk? I gather, if he takes a tumble, you'll be endangering world peace.

Mr. Napier: Don't worry about Kemal, he knows what he's doing on a horse.

(Downton Abbey, Episode 3)

This conversation happens between Mary and Mr. Napier. Earlier, Mr. Napier told Mary that a charming prince from Turkey was coming to the hunt. Mary was very happy with the news and eager to see this legendary man as soon as possible. Therefore, after long wait for this prince has set Mary's nerves on edge, and then she asked Mr. Napier "What about Mr. Pamuk? I gather, if he takes a tumble, you'll be endangering world peace". Of course we all know that the world peace will not break for his lateness, so what Mary's says were not true. On the one hand, Mary's implicature is that "why is the prince so slow to show up, and I can't wait to see him", which expressed her eagerness. On the other hand, Mary said if he took a tumble, the world peace will be endangered. From her utterance, we can see that Mary was worried if something urgent happened to him. "You'll be endangering world peace" is obviously an employment of hyperbole and the hyperbole is used to describe Mary's expectation and concern for the prince. Mary's utterances were not grounded on facts and violate the quality maxims.

\section{Conversational Implicature Created by Violating the Maxim of Relation}

According to Grice, the relation maxim refers to that the utterances made by speakers should be relevant to topic they are talking about, or the conversation would not go ahead. But in reality, people always violate the maxim of relation for some specific reasons or intentions. If the speakers' utterances really have nothing to do with the topic, they might give a hint to hearers that they don't want to go on with this topic. Sometimes, speakers are trying to hide something or keep the secret by saying something irrelevant. The following is a typical example from Downton Abbey:

\section{Example 6:}

O'Brien: Daisy? You know when you were talking about the feeling of death in the house?

Daisy: I was just being silly.

O'Brien: I found myself wondering about the connection between the poor Turkish gentleman, $\mathrm{Mr}$ Pamuk, and Lady Mary's room. Only you were saying how you felt so uncomfortable in there.

Daisy: Well. I've... I've got to get on. I'm late enough as it is.

(Downton Abbey, Episode 5) 
This conversation happened between Daisy and O'Brien. O'Brien is a deep person who is hard to see through, but Daisy is young and simple. From the plot ahead, we see that Pamuk died in Lady Mary's room, and no one else knew about it except for Cora, Mary and Anna. However, Daisy unwittingly found the truth. Therefore, O'Brien was going to get the truth of Pamuk's death from Daisy: "You know when you were talking about the feeling of death in the house, I found myself wondering about the connection between the poor Turkish gentleman, Mr Pamuk, and lady Mary's room. Only you were saying how you felt so uncomfortable in there." But Daisy was afraid of being fired for spreading rumors and dared not to tell the truth, so she replied: "Well. I've... I've got to get on. I'm late enough as it is." It is not difficult to see that Daisy's utterance had nothing to do with the question of O'Brien, so she violated the maxim of relation. Her conversational implicature was that she did not want to mention it again or she didn't know the truth.

\section{Conversational Implicature Created by Violating the Maxim of Manner}

The maxim of manner refers to "how to say" that could make a comfortable and successful conversation. It means that speaker should convey his utterance as clearly and briefly as possible. Actually, people always speak something obscure, ambiguous in a lengthy and disordered way, there is no doubt that speaker breaches the maxim of manner. There are lots of typical cases in Downton Abbey illustrating the maxim:

\section{Obscurity}

"Obscurity" points that some words spoken by people are difficult to understand or deal with, usually because they involves so many parts or detail. Therefore, speaker should say something as clear as possible in order to avoid violating the maxim of manner. However, sometimes speaker would not deliberately say something obscure, but an effective way to avoid embarrassment.

\section{Example 7:}

Robert: Mary can be such a child.

Cora: What do you mean, darling?

Robert: She thinks if you put a toy down, its still be sitting there when you want to play with it again.

Cora: What are you talking about?

Robert: Never mind.

(Downton Abbey, Episode 5)

At the dinner, Edith deliberately attracted Anthony's attention in order to try to annoy Mary. Mary disliked her sister Edith for her flattery. Therefore, after dinner Mary made an excuse on purpose to ask Anthony some questions. Mary's intention was to let Edith be neglected or made to feel missed out. However, Mary's approach did not take the feelings of
Matthew who deeply loved her into account, and Matthew, too, was left out on the pretext of a headache. Seeing the back of Matthew's departure, Mary never ceased regretting her actions. Robert watched the whole thing without comment, and then sighed that was just being childish and immature. Whereas the utterances made by Robert was spoken to Cora without her knowledge of the content, so that what he said was hard to catch for Cora. Thus Robert violated the maxim of manner: Do not be obscure. Robert wanted to convey the meaning that he was actually angry with Mary's behavior. The conversational implicature here showed Robert's unpleasantness about Mary.

\section{Ambiguity}

If hearer felt that there is an ambiguity in speaker's utterances, hearer would think that speaker deliberately provided unclear or confusing information, or his utterance could be understood in more than one way.

\section{Example 8:}

Joe Burns: I notice you call yourself missus.

Mrs Hughes: Housekeepers and cooks are always missus. You know better than anyone, I haven't changed my name.

Joe Burns: Well, I know you wouldn't change it to Burns when you had the chance.

(Downton Abbey, Episode 4)

In this conversation, there is a word "missus" which refers to a man's wife. If a woman called herself "missus" or was called "missus" by others, it means that she married. But from Mrs Hughes utterances: "I haven't changed my name". We know that Mrs Hughes was actually an unmarried single woman. The phrase "changed the name" actually is a pun and has two meanings in reality: one represents the change of original name. For example: He changed his name. Now we can call him Danny not Jenny. The other is that a married woman usually bears her husband's surname. Mrs Hughes violated the maxim of manner by saying a pun. Her conversational implicature here has two aspects: one is that she didn't want to tell others the truth that she was unmarried, the other is that she would like to imply Joe Burns that they two still had a chance to start a family. Therefore, in order to avoid embarrassment Mrs Hughes used ambiguous words to express her implied meaning.

\section{Prolixity}

According to cooperation principle, speaker is required to express something in a brief way. However, in real life, speaker always violates the manner maxim, expressing something unnecessary or redundant. In this way probably wants to emphasize something important or avoid embarrassment. This kind of expression is also a way to generate the conversational implicature. 


\section{Example 9:}

William: Daisy? Is that you? Is it the chicken in a sauce or the chicken with sliced oranges?

Daisy: Oh, thank you, blessed and merciful Lord! Thank you! It's the chicken in the sauce. I'll never do anything sinful again, I swear it! Not till I die.

(Downton Abbey, Episode 1)

Daisy is a simple girl who is always getting into trouble, while William is a considerate man who loved Daisy and always helped her get rid of trouble. In this conversation, Daisy delivered the wrong food due to her carelessness, but she was a female servants and could not go in the dinning room, so she had to ask for help to make up for her mistake. Luckily, to her great relief William did not know where the chicken should be put. Therefore, she corrected her mistake immediately, "Oh, thank you, blessed and merciful Lord! Thank you! It's the chicken in the sauce. I'll never do anything sinful again, I swear it! Not till I die." From Daisy's utterances, it is not difficult to see that her utterances had exceeded the amount she needed to tell William.

\section{Disorder}

Disorder in cooperative principle refers to that something was said by speaker illogically. According to cooperative principle, the speaker is required to provide his utterance logically, while in most cases, speaker cannot obey the manner maxim but violates it by saying something out of order or meaningless. But to some extent, these disordered utterances can reflect speaker's inner state, which may be nervous, anxious worried or fearful.

\section{For example: 10}

Mary: Do you have any idea what you're asking? I'd be ruined if they even knew we'd had this conversation, let alone if...

Pamuk: What? Don't worry. You'll still be a virgin for your husband.

Mary: Heavens, is this a proposal?

Pamuk: Also, no. I don't think our union would please your family.

Mary: I'm afraid not.

Pamuk: Nor mine. But...a little imagination...you won't be the first.

Mary: You and my parents have something in common. Pamuk: Oh?

Mary: You believe I'm much more of a rebel than I am. Now, please go. I'm not what you think I am...if it's my mistake, if I've let you on, I'm sorry, But...I'm not...no...I've never done anything...Won't it hurt? Is it safe?

(Downton Abbey, Episode 3)

Pamuk is very good looking and Mary fell in love with him at first sight, but he was very flirtatious. On the first day they met, Pamuk would like to spend the night with Mary together. Although Mary also loved him, she worried about that the shameful thing would ruin herself, even the reputation of Downton Abbey. She urged Pamuk to leave her room, but she did not organize her utterances in a logical way so that her utterances had little to do with her real intention. Therefore, she violated the maxim of manner by saying something in a disorder way and this made Pamuk even more fearless. Meanwhile, from her utterances "Won't it hurt? Is it safe?", we can see that she actually did not mind Pamuk's impolite behavior at all.

\section{CONCLUSION}

This paper is an analysis of the dialogues extracted from Downton Abbey. Through analyzing these typical dialogues, we know that people, in most cases, prefer violating the cooperative principle to observe it. The reasons why people always cannot strictly follow the maxims of $\mathrm{CP}$ are that they want to obey the social value, to be polite, or to avoid embarrassment and so on during their conversation. However, even if the speakers do not express their deep meaning in a direct way, listeners still can have a good understanding of their real intention. Compared with "expressing in a direct way", the application of conversational implicature is far more vivid and more in line with people's daily mode of communication. Exactly speaking, if the people as well as characters in Downton Abbey do not violate the maxims of the CP during their conversation, the utterances can hardly be vivid and real.

\section{REFERENCES}

1. [何自然. (2002).

2. 《语用学概论》 $[\mathrm{M}]$, 长沙: 湖南教育出版社。

3. [冯翠华. (1983).

4. 《英语修讋格》 $[\mathrm{M}]$, 北京: 商务印书馆。

5. [刘缃清. (1987).

6. 关于Leech的礼貌原则[J], 《外语教学与研究》第3期 42 -46 .

7. [孙玉]. (1994).

8. 格莱斯会话含义理论中的几个问题J], 《外语学刊》第4期 , $8-11$ 。

9. [徐盛桓]. (1996). 《会话含义理论新发展》 [M], 开封: 河南大学出 版社。

10. [戴抹玤匊. (2002).

11. 〈亲纸扁简明英语语言学教程》 $[\mathrm{M}]$, 上海 : 上海外语教育出 版社。

12. [沈家煊. (1987).

13. 语用学论题之一: 会话含义[J], 《国外语言学》第2期6875 。

14. [程雨民. (1983).

15. 格赖斯的“会话含义”与有关的讨论J], 《国外语言学》第2 期 111-123。

16. [钟百超. (1996).

17. 新格赖斯会话含义理论研究在我国的进展 J], 《外语学刊》 第5期 37-52。 
18. [陈 融. (1985).

19. 格莱斯的会话含义学说[J], 《外国语》第3 期63-67。

20. Edward, D., \& Mercer, N (eds.). (1987). Common Knowledge: The Development of Understanding in the Classroom [M]. London: Routledge.

21. Grice, H. P. (1967). Logical and Conversation [A]. In H. P. Grice Studies in the Way of Words [M]. Cambridge, Mass: Harvard University Press.

22. Grice, H. P. (1975). Logic and Conversation [A]. In Syntax and Semantics 3: Speech Acts [C], eds. P. Cole \& J. L. Morgan. 45-46. New York: Academic Press.

23. Kleifgen, J. A. (1990). Pre-Kindergarten Children's Second Discourse Learning [J]. Discourse
Processes, 13: 125-142.

24. Leech, G. N. (1983). Principle of Pragmatics [M]. New York: Longman Group Limited.

25. Levinson, S. C. (1983). Pragmatics [M]. New York: Cambridge University Press.

26. Rundquist, S. (1983). Indirectness: A Gender Study If Flouting Grice's Maxims [J]. Journal of Pragmatics, 18: 143-169.

27. Smith, N. V. \& D. Wilson (eds.). (1979). Modern Linguistics: The Results of Chomsky's Revolution [M]. Harmondsworth: Penguin.

28. Sperber, D. \& D. Wilson (eds.) (1986). Relevance: Communication and Cognition [M]. Oxford: Blackwell. 